\title{
Implementing a flipped model of instruction in the EFL listening classroom: Impact on comprehension
}

\author{
Ehsan Namaziandost * 1, Zohreh Rezaei ${ }^{2}$, Parisa Etemadfar ${ }^{3}$, Samir Alekasir ${ }^{4}$ \\ ${ }^{1}$ English Department, Faculty of Humanities, Shahrekord Branch, Islamic Azad \\ University, Shahrekord, Iran \\ 2 English Department, Faculty of Humanities, Najafabad Branch, Islamic Azad University, \\ Najafabad, Iran \\ ${ }^{3}$ English Department, Faculty of Letters \& Humanities, Shahrekord University, \\ Shahrekord, Iran \\ ${ }^{4}$ English Department, Faculty of Humanities, Islamic Azad University, Ahvaz Branch, \\ Ahvaz, Iran \\ * e.namazi75@yahoo.com (Corresponding Author)
} Published: September 25, 2020

\begin{abstract}
Inventive technologies have provided students greater ways to invest more productive time within the classrooms, such as listening class. However, the flipped model of instruction should be practiced as a way to engage students in the process of listening comprehension. This experimental study aimed to investigate the effects of the flipped classroom (FC) on advanced EFL learners' listening comprehension. Sixty Iranian advanced EFL learners (19 to 23 years old) participated in 14 sessions. Half of the students taught through the flipped model of instruction (experimental group) and the others through traditional instruction (control group). Using a before and after design, students were retested after seven weeks. Results showed that the means average resulted from the L2 listening comprehension test revealed those both groups showing increases in listening scores, but the experimental group's mean score was higher than in the control group. Therefore, the FC model's implementation in the context of teaching and learning L2 listening comprehension can lead to positive outcomes since they could engage students in the process of learning English. The implication of this study calls for the FC model implementation to engage students in listening comprehension in the chance to learn better and expand their educational knowledge.
\end{abstract}

Journal on English as a Foreign Language, 10(2), 385-401

p-ISSN 2088-1657; e-ISSN 2502-6615 
Keywords: flipped classroom; listening comprehension; advanced EFL learners

How to cite this paper (in APA style): Namaziandost, E., Rezaei, Z., Etemadfar, P., \& Alekasir, S. (2020). Implementing a flipped model of instruction in the EFL listening classroom: Impact on comprehension. Journal on English as a Foreign Language, 10(2), 385-401. https://doi.org/10.23971/jefl.v10i2.2065

DOI: https://doi.org/10.23971/jefl.v10i2.2065

As a brand-new teaching word phrase or term, the "flipped classroom" in education is not a revolutionary concept but so alluring. As the upturned teaching place, this teaching technique can be applied by assigning students to engage them in learning activities (Strayer, 2012). There are some main features to differentiate the flipped classroom from an inverted classroom as two new learning contexts. Students view video-recorded lessons outside of class in the flipped lab, thereby growing the opportunity for constructive study and practicing various activities in the classroom (Strayer, 2012). Through various procedures to run a flipped classroom, teachers try to use activities such as involving students to view or listen to home lessons and complete their assignments in the classroom. The flipped classroom can develop other skills (Bezzazi, 2019; Fulton, 2012). Also, learners can use their time to engage them in active learning activities (Hamdan et al., 2013). Many teachers have flipped their classrooms and evaluated them to increase instruction quality (McLaughlin et al., 2014). In short, flipped learning can be one way to reach quality instruction, such as in the listening class of language classrooms.

Firstly, to utilize accessible learning, video lessons were generated to provide sufficient contact with the education to those who were deprived of learning because of long distances. Teachers initiated producing videos that could serve multiple purposes: to support students off-site and help students present at lectures (Cascaval et al., 2007; Namaziandost et al., 2019). During the past decade, online classes have gained approval, particularly in a college education context. However, students regularly criticized the limited collaboration and interaction in a pure, connected class (Geçer \& Da $\breve{g}, 2012)$. The flipping classroom has been implemented through studying remotely by a series of video tutorials, which is supported by direct conversations and individual help.

Journal on English as a Foreign Language, 10(2), 385-401

p-ISSN 2088-1657; e-ISSN 2502-6615 
Kronholz (2012), a widely recognized online educator, popularized the flipped classroom through his website, Khan Academy. This website contains over 4,120 short educational videos, most detailing a specific math concept. Khan works problems step by step on each video. Kronholz's (2012) idea showed that youngsters would watch the videos at home and work on class problems, essentially 'flipping' the classroom. Students also frequent the website to get homework help when they are stuck on a problem. Teacher seeks to change the way students think about education, noting "the old classroom model simply doesn't fit our changing needs" (Kronholz, 2012, p. 1). In short, implementing a flipped classroom is practiced through video with the specific steps to solve problems such as in the listening classroom.

Educators have implemented inverted or flipped models in educational literature and have adopted them over the past few years (Moranski \& Kim, 2016). To supplement the learning model activities, teachers can use their videos to encourage students in a discussion situation (Brecht \& Ogilby, 2008; Finkel, 2012; Goodwin \& Miller, 2013; Kronholz, 2012). As an important impact of flipped classrooms on language learning, the teachers have tried to probe various classroom models. As a pedagogical practice, the flipped classroom reverses the traditional classroom model, usually by providing a learning content through a digital-based platform before class. It also formerly enables learners to engage in immersive community learning and/or significant problem-solving drills performed under the teacher's regulation throughout the class (Herreid \& Schiller, 2013). To be applied in engaging students, the flipped model of instruction provides content using a digital-based platform.

Some studies, such as by Butt (2014) and Gilboy et al. (2015), reached a consensus about the highly beneficial nature of the flipped classrooms when it comes to the context of teaching and learning. The flipped classrooms are considered as an eye-catching model of teaching new languages in educational contexts. Researchers have outlined specific educational benefits of the flipped classroom. Studies in this regard have concluded positive attitudes of students and teachers concerning the efficacious learning environment (e.g., Butt, 2014; Gilboy et al., 2015) and higher achievement informative/summative tests (e.g., (Amresh et al., 2013). A study conducted by Love et al. (2014) revealed that a flipped direct algebra plan was introduced to the students of a given course; most of them pointed out that the learning context structure helped them obtain an enhanced understanding of the title. Another investigation that attested the superiority of a flipped-based learning environment over other kinds of classes is the study of Amresh et al. (2013). They revealed that students accomplished

Journal on English as a Foreign Language, 10(2), 385-401

p-ISSN 2088-1657; e-ISSN 2502-6615 
significantly greater in a course program than students did in a similar typical course design on assignments and exams.

The current study aimed at scrutinizing the effect of flipped classroom on the students' listening comprehension. Listening is the first language component that children learn throughout their acquiring their mother tongue (Namaziandost \& Çakmak, 2020). It is the main layer of the learning process that acts as a building block for language and cognitive progress. It plays a decisive role in the learning and communication processes crucial for successful participation in life (Nunan, 1991). Listening is the Cinderella of language teaching that has been ignored by her elder sister-speaking (Namaziandost et al., 2019b). For most citizens, to be able to declare understanding of a second language, they should possess the ability to talk and write in that language. In terms of secondary abilities, listening and reading are their means to certain purposes, rather than purposes in themselves (Nunan, 1991).

Flipped learning, or the flipped classroom, can be defined as pedagogical practices that allow the students to learn their learning materials traditionally conveyed in classroom lectures preceding the beginning of their class. It is a way to transform the conventional teaching class into a more digital class providing the digital natives (Santosa, 2017). When introduced to the flipped learning environment, students pass the classroom stage participating in dynamic learning assignments and might also get an independently pointed comment from their teachers (Hamdan et al., 2013; Namaziandost et al., 2019). Many academic institutions have applied flipped-based classrooms' standards and examined such efforts to enhance the teaching-learning process (McLaughlin et al., 2014).

The works that analyzed understudies' encounters subjectively and semi trial or trial assessment of flipped classroom effect on learners' learning results have been confined by Zhao and Breslow (2013) and Namaziandost \& Çakmak (2020). The examinations all secured quantitative proportions of understudy learning. In looking into these investigations, 22 examinations actualized a flipped learning stage where online materials completely or mostly supplanted in-person addresses, and the measure of time committed to class was diminished. Four kinds of materials were used to fill in for a face to face addresses: online readings/tasks; long recordings (Lewis \& Harrison, 2012; Namaziandost \& Çakmak, 2020), numerous short video sections (Stone, 2012), and online instructional exercises with a mix of recordings, installed ten evaluations and activities, and pictures and messages (Lovett et al., 2008;

Journal on English as a Foreign Language, 10(2), 385-401

p-ISSN 2088-1657; e-ISSN 2502-6615 
Namaziandost \& Çakmak, 2020). Therefore, to the researchers' best knowledge, rare studies have been done on the flipped model's impact on listening comprehension.

A few examinations demonstrated a superior learning advantage for understudies in the flipped model in correlation with their partners in the customary model (Lewis \& Harrison, 2012). Different works led in such manner discovered huge impacts of the flipped model just for a subpopulation of the members (Riffell \& Sibley, 2005). Thus, it can be concluded that blended learning has numerous benefits for language learners to become successful in learning language skills and sub-skills. Consequently, the flipped classroom presents information before the classroom and makes students more engaged with the course contents before attending the class.

In analyzing the understudies' view of using the flipped model, it discovered blended, however commonly positive, understudy impression of the flipped classroom (Bishop \& Verleger, 2013). Using flipped learning, students have more positive attitudes during their learning English skills (Alhamami \& Khan, 2019; Fauzan \& Ngabut, 2018). It revealed that understudies favored intuitive in-class exercises were in contrast with addresses and shorter recordings. In any case, understudies were found of up close and personal talks contrasted with video addresses. Two-surveys contemplates concentrated on understudy learning results, and both revealed that understudy learning was improved. In one of the examinations, the class was just flipped multiple times, and there were smaller than usual talks in class. What's more, the consequence of the other investigation of a senior-level PC communication course alone was not adequate to help a summed-up guarantee on the viability of the flipped model (Bishop \& Verleger, 2013; Namaziandost et al. 2019).

Conversely, some studies have reported negative results for the flipped classroom. For instance, Herreid and Schiller (2013) conducted a study on the flipped classroom's efficiency; in her study, she outlined a few concerns about the flipped-classroom approach, including computer access after-hours for all students. Spencer et al. (2011) also pointed out the fact that in addition to prerecorded videos, in-class work should encompass features like inquired based activities and project-based learning. Also, Overmyer (2014) analyzed the FC model's impacts on undergrads' exhibition when executed regarding an advanced degree. The research's significance revealed no report of a measurably critical contrast in the marks of substitutes in the double get-

Journal on English as a Foreign Language, 10(2), 385-401

p-ISSN 2088-1657; e-ISSN 2502-6615 
togethers; nevertheless, replacements of the FC-based classes performed somewhat superior to understudies in the customary classes.

Szparagowski (2014) examined to investigate the "flipped" or "modified" classroom and its impacts on understudy learning. One of the essential highlights of the flipped homeroom is the arrangement of training. Wherein understudies will have the chance to grow their insight into the learning materials during out-of-class-time rather than the conventional survey practices that are ordinarily given, which furnishes the understudies with an opportunity to partake to take part in exercises, critical thinking, and different types of guidance. Szparagowski (2014) executed an FC model in a secondary school arithmetic course. To assemble the planned information, the scientist examined understudy reviews, a pre- and post-study, a class talk with/conversation, and the researcher's notes from instructing. The discoveries uncovered that actualizing the FC model could profit the educating learning forms from numerous points of view. Subsequently, the highlights of this model should not be overlooked by educators.

Lin and Chen (2016) analyzed the flipped model's impacts on the learning capability, though using learning success as the go-between. The results of their examination showed that as to the learning fulfillment, all the individuals from the specialized and professional universities (the primary half), including teachers and understudies, communicated their inspirational demeanor about the execution of the flipped learning model. Simultaneously, the second $50 \%$ of focused and skilled schools' replacements reasoned that applying the FC model could negatively affect learning fulfillment. Summing up the aforementioned, learning achievement has an incomplete interceding impact.

This study fills the rare research gap examining those variables regarding the importance of variables - flipped classrooms and listening comprehension - explained already. This study wants to examine the effects of the former one on the later one. The research question addressed in this study is as follows, "Do students taught in a flipped FL listening classroom have a higher listening comprehension score than those who taught through the traditional method?" 


\section{METHOD}

\section{Research Design}

An experimental method of research was used in this study (Creswell, 2009). Accordingly, the study employed a pretest and posttest design to extract needed data from one experimental group (EG) and one control group (CG). This study focused on flipped teaching as an independent variable and listening comprehension as a dependent variable hypothesized to be affected by the independent variable. The collected data were analyzed using one-way ANCOVA.

\section{Participants}

This study included 60 advanced students as its participants; they were chosen non-randomly from 100 students at a private English language institute in Isfahan, Iran, based on an Oxford Quick Placement Test (OQPT). All of these students were female, ranging in ages from 19-23. Their degree of English language capability was resolved based on their scores on OQPT. The learners were randomly divided into two equal groups of 30- experimental group and control group.

\section{Data Collection}

To collect the data, the OQPT test as a capability test replied by all the current examination members was first used. It helped the scientist pick the propelled learners; the individuals who scored between 50 and 60 were resolved as the development level. A researcher-made pretest was designed based on the students' materials to realize the current participants' listening comprehension level. It was a listening comprehension test of 40 objective items, including filling the blanks, true or false items, and multiple-choice items. A panel of English experts confirmed the pretest validity, and its reliability was computed using the KR-21 formula $(\mathrm{r}=.899)$. The pretest was piloted on another similar group to check the test's feasibility going to be administered to the target participants.

For doing so, 100 Iranian EFL learners from a private English language institute were selected. The OQPT test was then distributed among them. After answering the OQPT test, 60 advanced students were chosen as the target population of the study. They were then randomly divided into two equal experimental groups - experimental (EG) and control (CG). A researcher-made listening test pretested them. Next, the treatment was practiced in both groups.

Journal on English as a Foreign Language, 10(2), 385-401

p-ISSN 2088-1657; e-ISSN 2502-6615 
After that, the researchers put the EG participants in the flipped classroom and the CG in the non-flipped classroom. The flipped classroom was equipped with internet, computer, and projector, and participants in this classroom were allowed to bring their Smartphones to the classroom and use them during learning. The students in the flipped classrooms were given audio files. Each audio file was sent to the students via email, WhatsApp, or Telegram. Participants had the homework before attending the class. The teacher in the EG was a facilitator and coordinator in the learning process. The students were required to read each text before coming to the class and discuss it with their classmates. The teacher could elicit some students' information in the class, ask them some questions, or give them a test. The teacher also could ask them to listen and say its main idea. This procedure continued until the last session.

On the other hand, the students' non-flipped classroom in the CG was deprived of the mentioned facilities, and they were forbidden to use their smartphones while learning. The treatment lasted 14 sessions of 50 minutes each under the guidance of the supervisor. In the last session, both groups took the posttests of listening. The posttests of listening were similar to the pretest characteristics with different question orders. This test assessed students' listening comprehension after the treatment period and measured flipped classrooms' impacts on their listening comprehension skills.

\section{Data Analysis}

The collected data through the procedures mentioned earlier were analyzed and interpreted according to the study's objectives. Firstly, the Kolmogorov-Smirnov (K-S) test was used to check the normality of the gathered data. Then, the descriptive statistics were calculated using SPSS software, version 22. Finally, one-way ANCOVA was run to determine flipped classrooms' effectiveness on Iranian EFL learners' listening comprehension.

\section{FINDINGS}

First of all, the normality distribution was checked through the Kolmogorov-Smirnov test, as shown in Table 1. The Sig. value under the Kolmogorov-Smirnov part of Table 1 represents a value higher than .05, indicating that the pretest and posttest distribution was normal.

Journal on English as a Foreign Language, 10(2), 385-401

p-ISSN 2088-1657; e-ISSN 2502-6615 
Table 1. Kolmogorov-Smirnov results for the pretest and posttest

\begin{tabular}{lccc}
\multirow{2}{*}{ Tests } & \multicolumn{3}{c}{ Kolmogorov-Smirnov } \\
\cline { 2 - 4 } & Statistic & $\mathrm{df}$ & Sig. \\
\hline EG pretest & .152 & 30 & .075 \\
EG posttest & .334 & 30 & .121 \\
CG pretest & .239 & 30 & .091 \\
CG posttest & .267 & 30 & .123 \\
\hline
\end{tabular}

The study's final objective was to see if the flipped classroom significantly affects Iranian advanced EFL learners' listening comprehension. To fulfill this objective, the researcher had to compare the listening posttest scores of the EG and CG learners, for which an independent-sample t-test could be conducted. Nonetheless, to control any possible pre-existing differences between these two groups and compare their posttest scores accordingly, oneway ANCOVA was conducted.

Table 2. Descriptive statistics for comparing the posttest scores of the EG and CG learners

\begin{tabular}{cccc}
\hline Groups & Mean & Std. deviation & $\mathrm{N}$ \\
\hline EG & 16.30 & .87 & 30 \\
CG & 12.38 & .88 & 30 \\
Total & 14.34 & 2.15 & 60 \\
\hline
\end{tabular}

Table 2 shows that the posttest mean score of the EG1 learners $(M=16.30)$ was larger than the post-test mean score of the EG2 learners $(M=12.38)$. To find out whether this difference was a statistically significant one or not, it had to look down the Sig. column and in front of the group's row in Table 3.

Table 3. Results of one-way ANCOVA for comparing the posttest scores of the EG and CG learners

\begin{tabular}{lcccccc}
\hline \multicolumn{1}{c}{ Source } & $\begin{array}{c}\text { Type III } \\
\text { sum of } \\
\text { squares }\end{array}$ & df & $\begin{array}{c}\text { Mean } \\
\text { square }\end{array}$ & F & Sig. & $\begin{array}{c}\text { Partial } \\
\text { eta } \\
\text { squared }\end{array}$ \\
\hline Corrected & $242.418^{\mathrm{a}}$ & 2 & 121.209 & $\begin{array}{c}210.45 \\
7\end{array}$ & .000 & .881 \\
model & 30.11 & 1 & 30.11 & 52.28 & .000 & .47 \\
Intercept & 12.31 & 1 & 12.31 & 21.38 & .000 & .27 \\
Pretest & 211.09 & 1 & 211.09 & 366.53 & .000 & .86 \\
Groups & 32.82 & 57 & .57 & & & \\
Error & 12616.25 & 60 & & & & \\
Total & 275.246 & 59 & & & & \\
Corrected total & (Adjusted R Squared = .877) & & & \\
a. R Squared $=.881$ (Ad)
\end{tabular}

Journal on English as a Foreign Language, 10(2), 385-401

p-ISSN 2088-1657; e-ISSN 2502-6615 
Table 3 shows the row labeled groups in the leftmost column, and across this row, under the Sig. column. It is the $p$-value which should be compared to the alpha level of significance (i.e., .05). The $p$-value here was larger than the alpha level of significance $(.000>.05)$, indicating that the difference between the two groups of EG and CG on the listening posttest was statistically significant. This means that the flipped instruction model was significantly more effective than non-flipped instruction in improving EFL learners' listening comprehension. This is also shown in the bar chart in Figure 1.

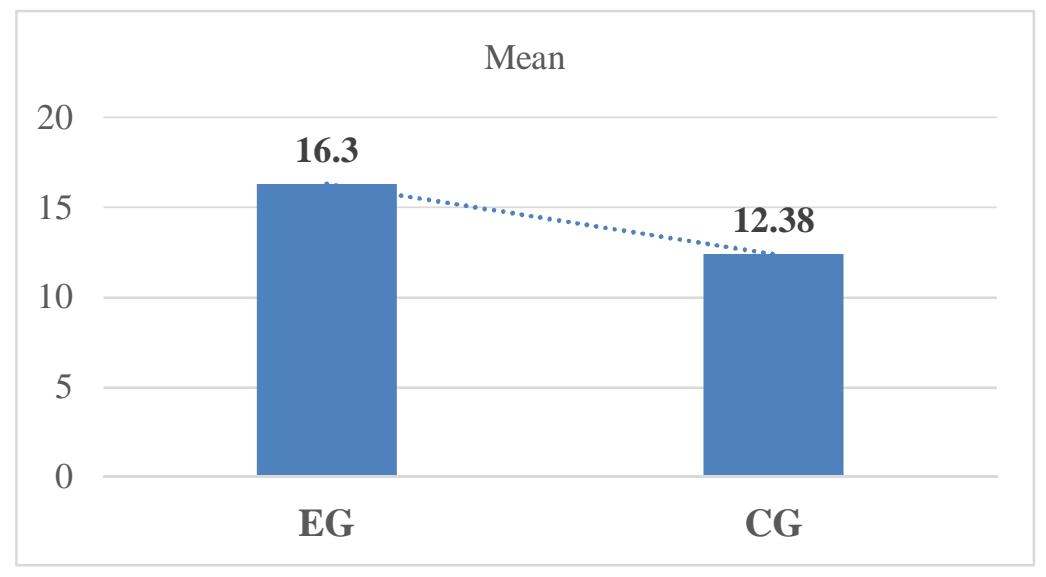

Figure 1. Posttest mean scores of the EG and CG

It could be clearly seen in Figure 1 that the difference between the listening posttest scores of the EG and CG learners was statistically significant, leading us to the conclusion that the flipped model of instruction was more effective than non-flipped instruction.

To get sure about both groups' performance from pretest to posttest, a paired-samples $t$-test was run. The descriptive statistics result of the pretest and posttest scores of the EG and CG are shown in Table 4.

Table 4. Descriptive statistics for comparing pretest and posttest scores of the EG and

\begin{tabular}{llcccc}
\multicolumn{7}{c}{ CG } \\
\hline & Mean & $\mathrm{N}$ & $\begin{array}{c}\text { Std. } \\
\text { deviation }\end{array}$ & $\begin{array}{c}\text { Std. error } \\
\text { mean }\end{array}$ \\
\hline \multirow{2}{*}{ Pair 1 } & EG posttest & 16.30 & 30 & .87 & .16 \\
& EG pretest & 12.50 & 30 & 1.27 & .23 \\
\multirow{2}{*}{ Pair 2 } & CG posttest & 12.38 & 30 & .88 & .16 \\
& CG pretest & 12.21 & 30 & .66 & .12 \\
\hline
\end{tabular}


Table 4 shows the difference between the pretest and posttest scores of the EG and CG learners. To find out whether this difference between the pretest and posttest scores was statistically significant or not, the following $t$-test table had to be checked.

Table 5. Results of the paired-samples $t$-test comparing pretest and posttest scores of the EG and CG

\begin{tabular}{llcccccc}
\hline & Mean & $\begin{array}{c}\text { Std. } \\
\text { deviation }\end{array}$ & $\begin{array}{c}\text { Std. error } \\
\text { mean }\end{array}$ & $\mathrm{t}$ & $\mathrm{df}$ & $\begin{array}{c}\text { Sig. (2- } \\
\text { tailed) }\end{array}$ \\
\hline Pair 1 & $\begin{array}{l}\text { EG posttest }- \\
\text { EG pretest }\end{array}$ & 3.80 & 1.24 & .22 & 16.74 & 29 & .000 \\
Pair 2 & $\begin{array}{l}\text { CG posttest }- \\
\text { CG pretest }\end{array}$ & .16 & .46 & .08 & 1.98 & 29 & .061 \\
\hline
\end{tabular}

Table 5 revealed that there was a statistically significant difference between the pretest and posttest scores of the EG learners since the $p$-value under the Sig, (2-tailed) column was smaller than the significance level (i.e., .00 $<.05$ ). This indicates that the treatment (using flipped classroom instruction) was effective so far as the Iranian advanced EFL learners' listening skills. Moreover, since Sig (.061) is higher than 0.05, the difference between the pretest and posttest of the CG is not significant. It can be concluded that non-flipped instruction was not effective to be used in the classrooms to improve EFL learners' listening skill.

\section{DISCUSSION}

In this part, the researcher discussed the results of the study that answered the question raised. It aimed to investigate the flipped classroom (FC) effects on advanced EFL learners' listening comprehension. After gathering the information, the specialist broke them down to discover flipped homerooms' viability on the understudies' listening cognizance. The discoveries demonstrated that the participants who got guidance through flipped classroom would be advised to execute contrasted with the individuals prepared through customary study hall. The outcomes factually uncovered that the test bunch essentially showed improvement over the benchmark group ( $\mathrm{p}<$ .05). Members in the flipped study halls were profoundly energetic to learn on account of the accessible offices. Flipped learning is commonly found to build inspiration (Bormann, 2014). In addition to the fact that they enjoyed learning, they also felt happy with what they realized. The test bunch increased higher scores on their posttest. This might be because of some engaging highlights the flipped homerooms have.

Journal on English as a Foreign Language, 10(2), 385-401

p-ISSN 2088-1657; e-ISSN 2502-6615 
In line with Prensky (2001), learners of the $21^{\text {st }}$ century as digital natives are more willing and ready to embark on technology-based learning scenarios representing paradigm shifts in conventional teaching and learning practices. Similarly, today's new generation of students is regularly exposed to the always-on digital world. Nowadays, most students view their smart devices as an integral feature of their learning experience; however, schools tend to ban smart devices. It is highly recommended that educational systems worldwide hold the digital society as a substitute for aggressive alongside it. Teachers need to be highly informed about the practical use of technology-mediated instruction and learn to embrace the pedagogical ways to implement technology in the context of their classes. The flipped model allows the teachers to replicate on their training and reflect on fine methods to grasp their pupils (Herreid \& Schiller, 2013).

FC makes it easier to help students. They will be provided with the capability of pausing, rewinding, and replaying the videos to help them gain a better understanding of the important notions. Using the FC model, the teachers could benefit their students by giving them more control over their learning. Consequently, the FC approach's implementation will provide a learning environment that brings about learning situations for students in which they can have their learning content personalized.

One of the FC model's main features is the important role of technology in enhancing the teacher-student interaction. This process is generally controlled by teachers in contexts where the FC model is implemented. Teachers will be able to dedicate time in order to inspire students. Implementing the flipping model permits separated learning materials to reach students with a broad range of abilities. The learning atmosphere that the FC model creates enables the students to work at their own pace and demonstrate mastery of learning, which would equip the teachers with the ability to adapt suitable jobs that are considered top fixed for them. In classrooms where the FC model is being implemented, the class management develops into a different type since, in this way, educators don't stance before the classroom speaking at the pupils.

These studies produced results that corroborate the findings of a great deal of the previous works where the FC model was implemented in their contexts (Bishop \& Verleger, 2013; Strayer, 2012). However, one positive difference from previous reports is that not one student 'strongly disliked' the changes reported by Bishop and Verleger (2013). Another implication 
concerning the positive views that could be elicited from these studies is that L2 students regularly would experience an increased sense of improvement, leading to enhanced student satisfaction.

Additionally, the findings are in accordance with Namaziandost et al. (2019), who claimed that the FC model played an important role in enhancing upper-intermediate EFL students' listening comprehension. Moreover, the outcomes of the current study contradict the study by Overmyer (2014) who scrutinized the efficiency of the flipped classroom model on students' progress in an algebra course. The findings indicated that the model neither helped nor facilitated the development of the students. Likewise, the results contradict the findings of the study by Johnson and Renner (2012). They concluded that implementing flipped classroom teaching will not benefit the computer application course. However, this study's results are in line with Szparagowski's (2014) who concluded that some potential benefits of the flipped classroom make it a form of education that teachers should not overlook. Moreover, this study's findings are consistent with Lin and Chen (2016) who indicated that flipped learning has a positive effect on learning effectiveness.

The flipped classrooms can equip the learning atmosphere with high beneficial features; these advantages may be associated with the supervisory direction centered upon the information representation that was created before class via pre-learning. From a pedagogical perspective, this study sheds light on the importance of a learning environment that encourages active and cohesive classroom interaction. It also contributes to considering how the environment for active learning can be better achieved by incorporating technology in pedagogical practices.

\section{CONCLUSION}

The obtained findings revealed that by attending the flipped classrooms, Iranian EFL students would have the chance to learn better and expand their educational knowledge. Learning the educational content via the flipped classroom can aid and expedite the learning of listening comprehension. It can also promote independence among students and help them gain confidence when studying outside. In regard to the efficacy and value of the flipped classroom, it is highly recommended that the FC model be implemented in educational contexts. The present study has provided a glimpse into how flipped classrooms can facilitate English language learning, particularly in

Journal on English as a Foreign Language, 10(2), 385-401

p-ISSN 2088-1657; e-ISSN 2502-6615 
listening comprehension. Future research should also extend the amount of time to determine the maintenance of treatment effects. Upcoming studies need to determine if the treatment is equally effective in diverse populations and other geographical locations. Further studies can include more participants to get richer findings; moreover, in studies with similar topics, both female and male students are recommended to be involved. Future research should look at different ages and a wider variety of environments to see how far flipped classrooms' benefits extend.

\section{DECLARATION OF CONFLICTING INTERESTS}

The authors declared no potential conflicts of interest with respect to the research, authorship, and/or publication of this article.

\section{REFERENCES}

Alhamami, M., \& Khan, M. R. (2019). Effectiveness of flipped language learning classrooms and students' perspectives. Journal on English as a Foreign Language, 9(1), 71-86. https://doi.org/10.23971/jefl.v9i1.1046

Amresh, A., Carberry, A. R., \& Femiani, J. (2013). Evaluating the effectiveness of flipped classrooms for teaching CS1. 2013 IEEE Frontiers in Education Conference (FIE), 733-735. https://doi.org/10.1109/FIE.2013.6684923

Bezzazi, R. (2019). The effect of flipped learning on EFL learners' public speaking in Taiwan. Journal on English as a Foreign Language, 9(1), 1-19. https://doi.org/10.23971/jefl.v9i1.1035

Bishop, J. L., \& Verleger, M. A. (2013). The flipped classroom: A survey of research. 120thASEE annual conference and exposition. Retrieved from http://www.asee.org/public/conferences/20/papers/6219/view.

Bormann, J. (2014). Affordances of flipped learning and its effects on Student engagement and achievement (Master thesis). University of Northern Iowa.

Brecht, H. D., \& Ogilby, S. M. (2008). Enabling a comprehensive teaching strategy: Video lectures. Journal of Information Technology Education: Innovations in Practice, 7, 71-86.

Butt, A. (2014). Student views on the use of a flipped classroom approach: Evidence from Australia. Business Education and Accreditation, 6(1), 33-43.

Cascaval, R. C., Fogler, K. A., Abrams, G. D., \& Durham, R. L. (2007). Evaluating the benefits of providing archived online lectures to in-class Math students. Journal of Asynchronous Learning Networks, 12(3), 61-70.

Journal on English as a Foreign Language, 10(2), 385-401

p-ISSN 2088-1657; e-ISSN 2502-6615 
Creswell, J. W. (2009). Editorial: Mapping the field of mixed methods research. Journal of Mixed Methods Research, 3(2), 95-108. https://doi.org/10.1177/1558689808330883

Fauzan, A., \& Ngabut, M. N. (2018). EFL students' perception on flipped learning in writing class. Journal on English as a Foreign Language, 8(2), 115-129. https://doi.org/10.23971/jefl.v8i2.792

Fulton, K. (2012). Upside down and inside out: Flip your classroom to improve student learning. Learning and Leading with Technology, 39(8), 12-17. Retrieved from https://eric.ed.gov/?id=EJ982840

Geçer, A., \& Dağ, F. (2012). A blended learning experience. Educational Sciences: Theory E Practice, 12(1), 438-442.

Gilboy, M., Heinerichs, S., \& Pazzaglia, G. (2015). Enhancing student engagement using the flipped classroom. Journal of Nutrition Education and Behavior. https://doi.org/10.1016/j.jneb.2014.08.008

Goodwin, B., \& Miller, K. (2013). Evidence on flipped classrooms is still coming in. Educational Leadership, 70(6), 78-80.

Hamdan, N., McKnight, P., McKnight, K., \& Arfstrom, K. M. (2013). A review of flipped learning. Flipped Learning Network, 1(1), 2-20.

Herreid, C. F., \& Schiller, N. A. (2013). Case studies and the flipped classroom. Journal of College Science Teaching, 42(5), 62-66.

Johnson, L., \& Renner, J. D. (2012). Effect of the flipped classroom model on a secondary computer applications course: Student and teacher perceptions, questions, and student achievement [University of Louisville]. http:/theflippedclassroom.files.wordpress.com/2012/04/johnson-renner2012.pdf

Kronholz, J. (2012). Can Khan move the bell curve to the right? Education Digest, 78(2), 23-30. Retrieved from https://eric.ed.gov/?id=EJ968950

Lewis, J. S., \& Harrison, M. A. (2012). Online delivery as a course adjunct promotes active learning and student success. Teaching of Psychology, 39(1), 72-76. https://doi.org/10.1177 0098628311430641

Lin, P.-C., \& Chen, H.-M. (2016). The effects of flipped classroom on learning effectiveness: Using learning satisfaction as the mediator. World Transactions on Engineering and Technology Education, 14(12), 231-244.

Love, B., Hodge, A., Grandgenett, N., \& Swift, A. W. (2014). Student learning and perceptions in a flipped linear algebra course. International Journal of Mathematical Education in Science and Technology, 45(3), 317-324. https://doi.org/10.1080/0020739X.2013.822582

Lovett, M., Meyer, O., \& Thille, C. (2008). The open learning initiative: Measuring the effectiveness of the OLI statistics course in accelerating 
student learning. Journal of Interactive Media in Education, 1, 1-16. https://doi.org/10.5334/2008-14

McLaughlin, J. E., Roth, M. T., Glatt, D. M., Gharkholonarehe, N., Davidson, C. A., Griffin, L. M., Esserman, D. A., \& Mumper, R. J. (2014). The flipped classroom: A course redesign to foster learning and engagement in a health professions school. Academic Medicine: Journal of the Association of American Medical Colleges, 89(2), 236-243. https://doi.org/10.1097/ACM.0000000000000086

Moranski, K., \& Kim, F. (2016). 'Flipping' lessons in a multi-section Spanish course: Implications for assigning explicit grammar instruction outside of the classroom. The Modern Language Journal, 100(4), 830-852. https://doi.org/10.1111/modl.12366

Namaziandost, E., \& Çakmak, F. (2020). An account of EFL learners' selfefficacy and gender in the flipped classroom model. Education and Information Technologies, 25(5), 4041-4055. https://doi.org/10.1007/s10639020-10167-7

Namaziandost, E., Neisi, L., Mahdavirad, F., \& Nasri, M. (2019). The relationship between listening comprehension problems and strategy usage among advance EFL learners. Cogent Psychology, 6(1), 1-19. https: //doi.org/10.1080/23311908.2019.1691338

Namaziandost, E., Neisi, L., \& Momtaz, S. (2019). The effectiveness of flipped classroom model on listening comprehension among Iranian upperintermediate EFL learners. Journal of Applied Linguistics and Language Research, 6(4), 129-139.

Nunan, D. (1991). Language teaching and methodology: A text book for teaching. New York: Prentice Hall International.

Overmyer, G. R. (2014). The flipped classroom model for college algebra: Effects on student achievement (Unpublished dissertation). Colorado State University, Fort Collins. Retrieved from http:/hdl.handle.net/10217/83800

Prensky, M. (2001). Digital natives, digital immigrants. From on the Horizon (MCB University Press), 9(5), 1-6.

Riffell, S., \& Sibley, D. (2005). Using web-based instruction to improve large undergraduate biology courses: An evaluation of a hybrid course format. $\begin{array}{llll}\text { Computers } & \mathcal{E} & \text { Education, 217-235. }\end{array}$ https://doi.org/10.1016/.compedu.2004.01.005

Santosa, M. H. (2017). Learning approaches of Indonesian EFL Gen Z students in a Flipped Learning context. Journal on English as a Foreign Language, 7(2), 183-208. https://doi.org/10.23971/jefl.v7i2.689 
Stone, B. B. (2012). Flip your classroom to increase active learning and student engagement. In Proceedings of the 28th Annual Conference on Distance Teaching and Learning. Retrieved from http://www.uwex.edu/disted/conference/Resource_library/proceedings $/ 5$ 6511_2012.pdf

Strayer, J. F. (2012). How learning in an inverted classroom influences cooperation, innovation and task orientation. Learning Environments Research, 15(2), 171-193. https://doi.org/10.1007/s10984-012-9108-4

Szparagowski, R. (2014). The effectiveness of the flipped classroom. Honors Projects, 127, 1-31.

Zhao, Y. R., \& Breslow, L. (2013). Literature review on hybrid/blended learning. Unpublished manuscript, HarvardX, Harvard University, Cambridge, MA.

\section{Authors' Brief CV}

Ehsan Namaziandost holds an MA degree in TEFL from the Islamic Azad University of Ahvaz. Now, he is a Ph.D. candidate of TEFL at Islamic Azad University, Shahrekord, Iran. His research interests are TEFL, CALL, SLA, EFL teaching and learning, language learning and technology, teaching language skills, and language learning strategies.

Zohreh Rezaei holds a master's degree in TEFL from the Islamic Azad University of Najafabad, Isfahan, Iran. Her areas of interest are discourse analysis, pragmatics, and reading comprehension.

Parisa Etemadfar is an MA student in TEFL at the Shahrekord University, Iran. Her areas of interest are vocabulary learning and teaching, teaching language skills.

Samir Alekasir holds an MA degree in TEFL from the Islamic Azad University of Ahvaz. He is working in the department of public relations at the Khuzestan Educational Headquarters. He also has worked as an EFL teacher at the Ministry of Education, Iran. His areas of interest are CALL, MALL, MOOC, long-distance learning, and formative assessment.

Journal on English as a Foreign Language, 10(2), 385-401

p-ISSN 2088-1657; e-ISSN 2502-6615 